\title{
LUMINESCENCE DATING OF VOLCANOGENIC OUTBURST FLOOD SEDIMENTS FROM ASO VOLCANO AND TEPHRIC LOESS DEPOSITS, SOUTHWEST JAPAN
}

\author{
SUMIKO TSUKAMOTO ${ }^{1}$, KYOKO S. KATAOKA ${ }^{2}$ and YASUO MIYABUCHI ${ }^{3}$ \\ ${ }^{1}$ Leibniz Institute for Applied Geophysics, Stilleweg 2, Hannover D-30655, Germany \\ ${ }^{2}$ Research Institute for Natural Hazards and Disaster Recovery, Niigata University, \\ Ikarashi 2-8050, Nishi-ku, Niigata 950-2181, Japan \\ ${ }^{3}$ Faculty of Education, Kumamoto University, Kurokami 2-40-1, Chuo-ku, Kumamoto 860-8555, Japan
}

Received 31 January 2013

Accepted 9 September 2013

\begin{abstract}
Luminescence dating has been applied to volcanogenic outburst flood sediments (Takuma gravel bed) from Aso volcano, Japan, and tephric loess deposits overlying the gravel bed. The polymineral fine grains $(4-11 \mu \mathrm{m})$ from loess deposits were measured with pulsed optically stimulated luminescence (pulsed OSL) and post-IR infrared stimulated luminescence (pIRIR) methods, whereas the Takuma gravel bed containing no quartz, was measured with IRSL and pIRIR methods using sand sized $(150-200 \mu \mathrm{m})$ plagioclase. The loess deposits date back at least to $\sim 50$ ka by consistent IRSL, pIRIR and pulsed OSL ages from the lowermost part of the loess deposits from one section. The ages obtained from the bottom part of the other loess section are not consistent each other. However, we consider that the pIRIR age $(72 \pm 6 \mathrm{ka})$ which showed negligible anomalous fading is most reliable, and regard as a preliminary minimum age of the Takuma gravel bed. The equivalent doses $\left(\mathrm{D}_{\mathrm{e}}\right)$ for the plagioclase from the Takuma gravel bed have a narrow distribution and the weighted mean of the three samples yield an age of $89 \pm 3 \mathrm{ka}$. This age is in agreement with the last caldera-forming eruption of Aso volcano $(\sim 87 \mathrm{ka})$ and it is likely that the pIRIR signal has not been bleached before the deposition. IRSL dating without applying pIRIR using small aliquots was also conducted, however, the IRSL signal shows no clear evidence of an additional bleaching during the event of outburst flood from the caldera lake.
\end{abstract}

Keywords: IRSL, post-IR IRSL, tephric loess, Takuma gravel bed, Aso volcano, volcanogenic outburst flood.

\section{INTRODUCTION}

Aso volcano is one of the largest caldera volcanoes in Japan and its caldera forming eruptions provided four large-volume ignimbrites namely Aso-1, $-2,-3$ and -4 in the past ca. 270 ka (Ono et al., 1977; Machida and Arai,

Corresponding author: S. Tsukamoto

e-mail: sumiko.tsukamoto@liag-hannover.de
2003). It has been suggested that a caldera lake was once formed and then drained, after the Aso-4 eruption at $\sim 87 \mathrm{ka}$ (Aoki, 2008), according to the existence of lake sediments in the caldera (Watanabe, 1998; Kataoka and Miyabuchi, 2011). To the west of the caldera rim, a largescale volcaniclastic apron is distributed along the Shira River. The apron sediments (Takuma gravel bed) directly overlie the Aso-4 pyroclastic flow deposits and the Aso-4 lahar deposits, indicating that the gravel bed was formed 
after the eruption of Aso-4. The Takuma gravel bed is composed of poorly sorted pebble and cobble with sandy matrix, and occasionally contains large boulders up to a few metres in diameter. The present Shira River does not have the capacity to transport such boulder rich sediments, and therefore the sediment is presumably the result of a gigantic outburst flood from the caldera lake (Kataoka and Miyabuchi, 2011).

Volcanogenic large-scale flood sediments which are associated with caldera lake outburst or failure of volcanically dammed lake have been found in many places, e.g. Numazawa and Towada volcanoes, Japan (Kataoka et al., 2008; Kataoka, 2011), Aniakachak volcano, Alaska (Waythomas et al., 1996), Laacher See volcano, Germany (Park and Schmincke, 1997) and Taupo volcanic zone, New Zealand (Manville et al., 1999). In this study, we apply luminescence dating for the first time to volcanogenic outburst flood sediments from Aso volcano (Takuma gravel bed) and also to the overlying tephric loess deposits to constrain the age of the possible intra-caldera lake outburst event.

\section{STUDY AREA AND SAMPLES}

Partly terraced volcaniclastic apron surface in west of Aso caldera has been subdivided into the Takuma and Hotakubo surfaces (Watanabe et al., 1995). The higher Takuma surface (30-70 $\mathrm{m}$ a.s.l.) is a depositional surface of Takuma gravel bed and lower Hotakubo surface ( $\sim 20 \mathrm{~m}$ a.s.l.) is presumably an erosional surface (fillstrath terrace). The latter surface is covered by $1.5-2 \mathrm{~m}$ tephric loess, which contains two horizons of volcanic glasses concentration derived from two widespread tephra (Kikai-Akahoya tephra, $6.3 \mathrm{ka}$ and Aira-Tanzawa tephra, $29 \mathrm{ka})$ at $\sim 0.3 \mathrm{~m}$ and $0.8-1.2 \mathrm{~m}$ from the surface, respectively (Watanabe et al. 1995). According to the thickness of the loess and the stratigraphic horizons of

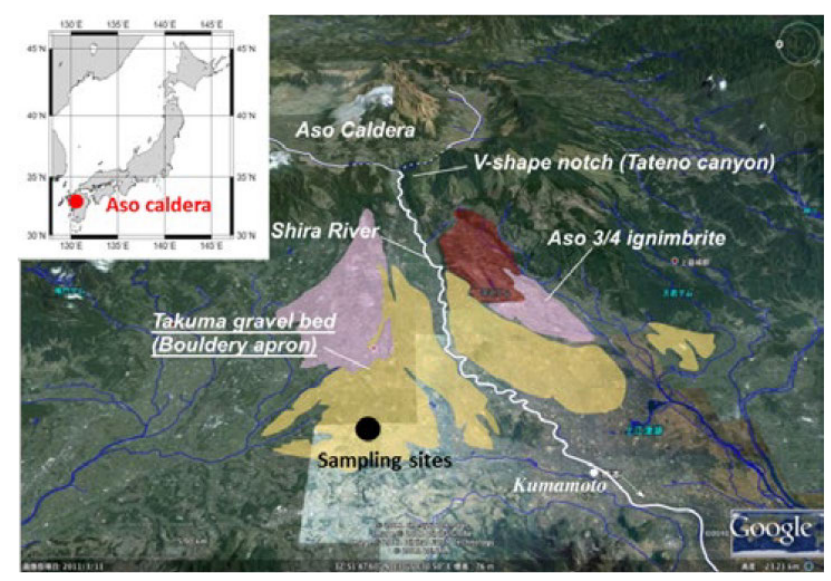

Fig. 1. Overview of Aso caldera and the distribution of volcanic apron (modified from Kataoka and Miyabuchi, 2011). Location of sampling sites is shown in black circle. Inset shows a map showing the location of Aso caldera. widespread tephra in the loess sequence, Watanabe et al. (1995) assumed that the Hotakubo surface was formed at 40-50 ka. Therefore, the age of the Takuma surface is older than 40-50 ka and younger than Aso-4 ( $\sim 87 \mathrm{ka})$.

Samples for luminescence dating were taken from two outcrops in the area of the National Agriculture Research Center for Kyushu Okinawa Region which is located about $25 \mathrm{~km}$ from the west of the breached caldera rim, close to the lower edge of the Takuma surface (Fig. 1). These outcrops are located at the wall of two trenches which were made for collecting surface water in case of heavy rain, in order to protect the area from flooding. The Takuma gravel bed and tephric loess are nicely exposed on the walls. Altogether, ten samples for luminescence dating were taken from Takuma gravel bed and tephric loess overlying the gravel bed. At Site 1 ("Mizuana-4", i.e., trench no. $4: 32^{\circ} 52^{\prime} 30.3^{\prime \prime} \mathrm{N} / 130^{\circ} 44^{\prime} 38.0^{\prime \prime} \mathrm{E}$ ), $\sim 3 \mathrm{~m}$ thick tephric loess covers the Takuma gravel bed (Fig. 2a). The upper $1 \mathrm{~m}$ of the tephric loess comprises so-called Kuroboku soil (black andisols) which is a typical dark coloured humic soil found near active volcanoes in Japan. The Takuma gravel bed here is more than $3 \mathrm{~m}$ thick, and shows crude parallel to low-angle cross stratifications which suggest a rapid deposition by a hyperconcentrated flow process (Kataoka and Miyabuchi, 2011). Four samples from tephric loess (AS-TL-1, -2, -3, 4) and two samples from the Takuma gravel bed (AS-TGB-1 and -2) were collected from this site.

Site 2 ("Mizuana-2", trench no. 2: $32^{\circ}$ 52' 55.4", $\mathrm{N} / 130^{\circ} 44^{\prime} 40.8^{\prime \prime}$ E) is located 700 m northeast of Site 1 . At this site, about $4 \mathrm{~m}$ of diffusely stratified Takuma gravel bed including metre-sized boulders and $\sim 2.5 \mathrm{~m}$ thick tephric loess are exposed (Fig. 2b). Three samples from tephric loess (AS-TL-7, -8, and -9) and one sample (AS-TGB-4) from the uppermost part of the Takuma gravel bed were taken for luminescence dating from Site 2.

\section{SAMPLE PREPARATION AND LUMINES- CENCE EQUIPMENTS}

The Takuma gravel bed comprises volcaniclastic materials which were derived mainly from the Aso 1-4 ignimbrites and pre-Aso volcanic rocks (Ono and Watanabe, 1985) entrained by the watery flow. An X-ray diffraction analysis of samples from the gravel bed (ASTGB-1, 2, and 4) indicates that these samples contain plagioclase, clino- and ortho-pyroxynes, magnetite, and hornblende, as well as volcanic glass shards. These minerals reflect the typical dacitic composition of Aso volcano. The sample TGB-4, taken close to the upper surface of TGB, also contains short-range order minerals (imogolite and/or allophane) which are commonly developed in volcanic soils in Japan (Wada, 1987). These samples do not yield quartz and K-feldspar which are normally used as luminescence dosimeters. Therefore, a sand-sized $(150-200 \mu \mathrm{m})$ plagioclase rich fraction was separated from heavy minerals using a sodium polytungstate solu- 
(a)

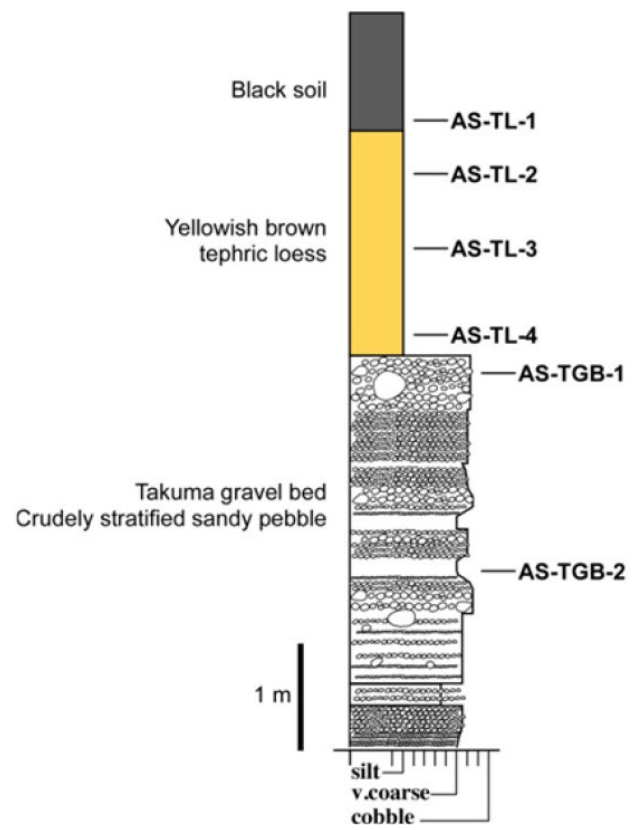

(b)

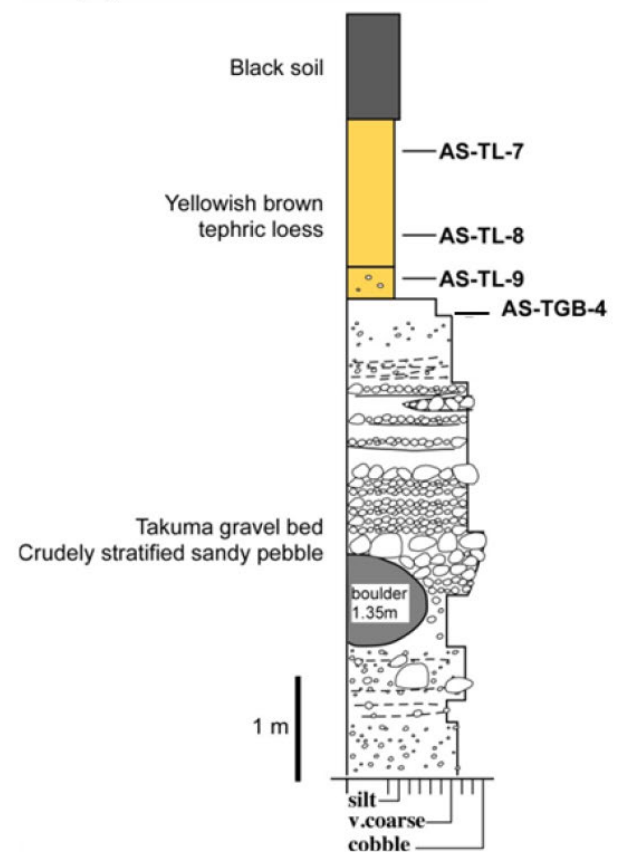

Fig. 2. Graphic sedimentary logs at (a) Site 1, so-called "Mizuana-4" and (b) Site 2, "Mizuana-2". The positions of luminescence samples are shown. tion $(\mathrm{d}<2.68)$ for AS-TGB-1, -2 , and -4 , after treating with hydrochloric acid $(\mathrm{HCl})$, sodium oxalate $\left(\mathrm{Na}_{2} \mathrm{C}_{2} \mathrm{O}_{4}\right)$ and hydrogen peroxide $\left(\mathrm{H}_{2} \mathrm{O}_{2}\right)$. For tephric loess samples, polymineral fine grains $(4-11 \mu \mathrm{m})$ were prepared using a standard procedure following Frechen et al. (1996). The sand sized grains were mounted on stainless steel discs using silicon spray for luminescence measurements using either 6 or $2.5 \mathrm{~mm}$ mask size. Polymineral fine grains were settled on aluminium discs using acetone or distilled water.

All luminescence measurements were carried out by an automated reader (Risø TL/OSL-20) equipped with blue and IR LEDs for optical stimulation and a ${ }^{90} \mathrm{Sr} /{ }^{90} \mathrm{Y}$ beta source $(1.48 \mathrm{GBq})$ for irradiation. Infrared stimulated luminescence (IRSL) signals were detected through a combination of $2 \mathrm{~mm}$ thick Schott BG-39 and $4 \mathrm{~mm}$ thick Corning 7-59 filters (detection: 320-460 nm). Pulsed optically stimulated luminescence (OSL) signals were measured with $50 \mu$ s on- and off-times, and only the offtime signal starting at $2.5 \mu \mathrm{s}$, after the pulses switched off, was recorded. A $7.5 \mathrm{~mm}$ HOYA U-340 $(280-360 \mathrm{~nm})$ was used as a detection filter for pulsed OSL measurements.

\section{LUMINESCENCE DATING}

\section{Dose rate}

High-resolution gamma spectrometry with an N-type coaxial detector was used for the estimation of external dose rates. For each sample, homogenised material of $50 \mathrm{~g}$ was used for gamma spectrometry measurements. The activities of ${ }^{234} \mathrm{Th},{ }^{214} \mathrm{Bi},{ }^{214} \mathrm{~Pb}$ (for $\mathrm{U}$ ), ${ }^{228} \mathrm{Ac},{ }^{208} \mathrm{Tl}$,
${ }^{212} \mathrm{~Pb}$ (for $\mathrm{Th}$ ) and ${ }^{40} \mathrm{~K}$ were converted into $\mathrm{U}$, Th and $\mathrm{K}$ concentrations to calculate annual dose rate using the conversion factors by Guérin et al. (2011). Natural water contents (water/dry sediment) were measured for all samples soon after sampling, however, as mentioned above, the studied sections are the walls of water reservoirs to collect surface water, and some of the measured contents were very high (up to $104 \%$ and $37 \%$ for tephric loess and the Takuma gravel bed, respectively). These measured water contents are probably much higher than the water contents for the samples averaged over the burial time. Therefore, we used a water content of $15 \%$ (assuming an uncertainty of $\pm 10 \%$ ) obtained from the Takuma gravel bed outside the National Agriculture Research Center to calculate dose rates for all Takuma gravel bed samples. A water content of $60 \%( \pm 20 \%)$ was used for tephric loess samples, which was measured from a wall from another trench wall in the research centre under a relatively dry condition. Alpha efficiencies (a-values) of $0.09 \pm 0.02,0.11 \pm 0.02$, and $0.035 \pm 0.03$ were used for IRSL, post-IR IRSL, and pulsed OSL signals, respectively (Kreuzer et al., submitted; Lai et al., 2008). The cosmic dose rate was calculated according to the altitude and geomagnetic latitude from the sampling sites, and the sampling depth from the surface based on Prescott and Hutton (1994). The total dose rates are summarised in Table 1.

\section{Post-IR IRSL (pIRIR) and pulsed OSL dating of tephric loess}

For dating of tephric loess, the luminescence from polymineral fine grains were measured using two differ- 
ent methods, i.e. post-IR IRSL (pIRIR) to measure feldspar luminescence and pulsed OSL to measure to quartz signal. Tephric loess in Japan has been considered to be a mixture of air-fall tephra from small-scale volcanic eruptions, loess from the Asian continent, and local dusts from adjacent non-vegetated areas (Suzuki, 1995; Tsukamoto et al., 2003). It has been reported that OSL dating of fine grain quartz from Japanese tephric loess is often problematic (Tsukamoto et al., 2003; Watanuki et al., 2005), because volcanic quartz has undesirable OSL characteristics (Tsukamoto et al., 2007). Such problem does not exist when the pIRIR protocol is applied (Thiel et al., 2011b). Since the study area does not have any source of quartz, it is expected that the pulsed OSL from quartz works well only if there is enough amounts of aeolian loess from the Asian continent.

For pulsed OSL luminescence signals are stimulated by pulsed LED light instead of normal continuous wave stimulation (Denby et al., 2006; Lapp et al., 2009). The lifetime of feldspar OSL signal is much shorter than that of quartz OSL, i.e. the feldspar signal decays quickly after the LED pulses switch off, and therefore when a luminescence signal from a mixture of quartz and feldspar is measured, the off-time signal should be dominated by quartz OSL.

\section{IRSL and PIRIR}

A single aliquot regenerative dose (SAR) protocol using a post-IR IRSL signal at $290^{\circ} \mathrm{C}\left(\mathrm{pIRIR}{ }_{290}\right)$ after preheated the samples at $320^{\circ} \mathrm{C}$ for $60 \mathrm{~s}$ and bleached with IR at $50^{\circ} \mathrm{C}$ for $100 \mathrm{~s}$ (Table 2) was applied for $\mathrm{D}_{\mathrm{e}}$ measurements. This protocol, first introduced by Thiel et al. (2011a), has been successfully applied to both polymineral fine grains and $\mathrm{K}$-feldspar without a fading correction (e.g. Buylaert et al., 2012). The pIRIR 290 signal was measured for $200 \mathrm{~s}$, but the IR LEDs were switched on $5 \mathrm{~s}$ after the temperature reached to $290^{\circ} \mathrm{C}$, in order to monitor thermally stimulated signal if any. No significant thermal signal was detected. The integrated intensity of the initial $5 \mathrm{~s}$ minus the last $25 \mathrm{~s}$ signal as background was used for the $D_{e}$ calculation. The $D_{e}$ values from the IRSL signal $\left(\mathrm{IR}_{50}\right)$ prior to pIRIR 290 were also calculated using the integrated intensity of the initial $4 \mathrm{~s}$ signal minus the last $10 \mathrm{~s}$. The second regenerative dose (74 Gy) cycle was repeated once again after measuring the highest regenerative dose cycle, and the recycling ratio was calculated for all measured aliquots. The $\mathrm{D}_{\mathrm{e}}$ values were calculated only from the aliquots which gave the recycling ratio within $10 \%$ from the unity.

A dose recovery test was conducted after bleaching aliquots using a solar simulator (SOL2) for 4 hours and giving a beta dose of $123 \mathrm{~Gy}$, in order to test if the ap-

Table 1. Summary of dose rate.

\begin{tabular}{|c|c|c|c|c|c|c|c|}
\hline Sample & $\underset{(p p m)}{U}$ & $\begin{array}{c}\text { Th } \\
(p p m)\end{array}$ & $\begin{array}{l}K \\
(\%)\end{array}$ & $\begin{array}{l}\text { Cosmic dose rate } \\
\text { (Gy/ka) }\end{array}$ & $\begin{array}{c}\text { Dose rate for } \\
\text { IRSL } \\
\text { (Gy/ka) }\end{array}$ & $\begin{array}{c}\text { Dose rate for } \\
\text { pIRIR } \\
\text { (Gy/ka) }\end{array}$ & $\begin{array}{c}\text { Dose rate for } \\
\text { pulsed OSL } \\
\text { (Gy/ka) }\end{array}$ \\
\hline AS-TL-1 & $3.96 \pm 0.04$ & $15.0 \pm 0.11$ & $1.25 \pm 0.02$ & $0.19 \pm 0.02$ & $2.93 \pm 0.21$ & $3.11 \pm 0.21$ & $2.42 \pm 0.17$ \\
\hline AS-TL-2 & $4.24 \pm 0.04$ & $17.2 \pm 0.11$ & $1.37 \pm 0.02$ & $0.17 \pm 0.02$ & $3.21 \pm 0.22$ & $3.42 \pm 0.22$ & $2.65 \pm 0.17$ \\
\hline AS-TL-3 & $3.77 \pm 0.04$ & $15.0 \pm 0.10$ & $1.23 \pm 0.02$ & $0.16 \pm 0.02$ & $2.85 \pm 0.21$ & $3.03 \pm 0.21$ & $2.35 \pm 0.17$ \\
\hline AS-TL-4 & $3.27 \pm 0.04$ & $12.4 \pm 0.09$ & $1.22 \pm 0.02$ & $0.14 \pm 0.01$ & $2.52 \pm 0.2$ & $2.67 \pm 0.20$ & $2.10 \pm 0.17$ \\
\hline AS-TL-7 & $4.16 \pm 0.03$ & $16.6 \pm 0.08$ & $1.36 \pm 0.01$ & $0.17 \pm 0.02$ & $3.14 \pm 0.22$ & $3.34 \pm 0.22$ & $2.59 \pm 0.17$ \\
\hline AS-TL-8 & $3.62 \pm 0.04$ & $13.3 \pm 0.09$ & $0.95 \pm 0.02$ & $0.16 \pm 0.02$ & $2.52 \pm 0.2$ & $2.69 \pm 0.20$ & $2.07 \pm 0.17$ \\
\hline AS-TL-9 & $2.57 \pm 0.04$ & $10.1 \pm 0.08$ & $1.07 \pm 0.02$ & $0.16 \pm 0.02$ & $2.11 \pm 0.19$ & $2.24 \pm 0.19$ & $1.78 \pm 0.16$ \\
\hline AS-TGB-1 & $2.25 \pm 0.04$ & $9.30 \pm 0.10$ & $1.68 \pm 0.03$ & $0.13 \pm 0.01$ & $2.59 \pm 0.17$ & $2.62 \pm 0.17$ & \\
\hline AS-TGB-2 & $2.45 \pm 0.03$ & $9.58 \pm 0.09$ & $1.74 \pm 0.02$ & $0.11 \pm 0.01$ & $2.68 \pm 0.17$ & $2.71 \pm 0.17$ & \\
\hline AS-TGB-4 & $2.40 \pm 0.04$ & $9.24 \pm 0.10$ & $1.37 \pm 0.02$ & $0.15 \pm 0.01$ & $2.38 \pm 0.17$ & $2.41 \pm 0.17$ & \\
\hline
\end{tabular}

Table 2. IRSL and post-IR IRSL protocols used in this study.

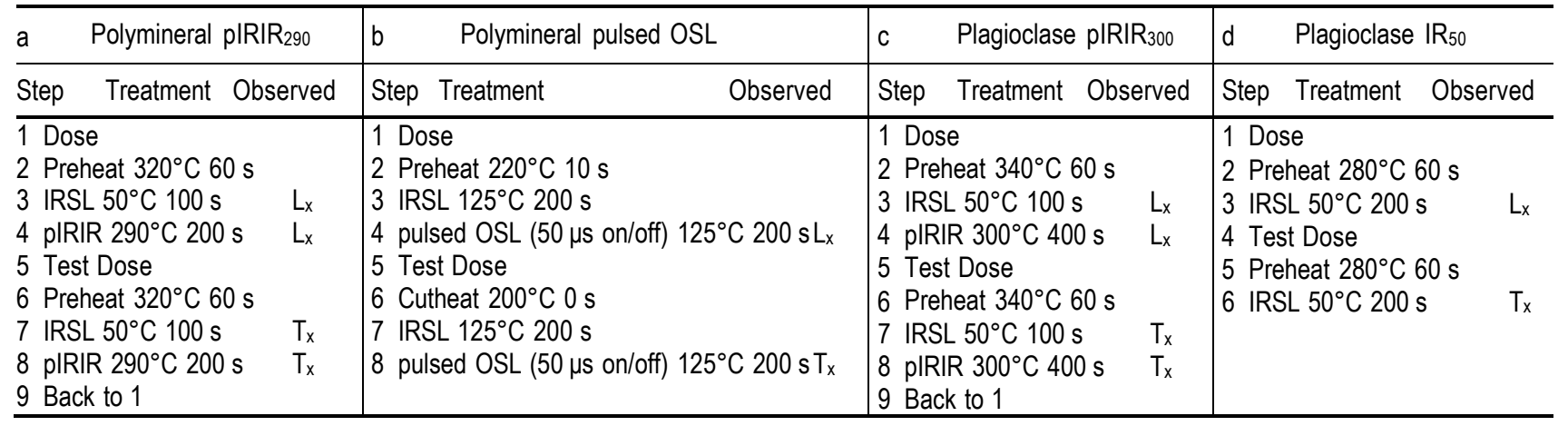


plied protocol can recover the known given dose. The residual dose after the 4 hour bleaching was also measured (Table 3) and subtracted from the recovered dose when the dose recovery ratio was calculated. However, the residual doses were not subtracted from the $\mathrm{D}_{\mathrm{e}}$ values. Sohbati et al. (2012) and Buylaert et al. (2012) reported an increase in measured residual doses with $D_{e}$ values, after a $4 \mathrm{~h}$ SOL2 bleaching. They interpret that the SOL2 bleach could not reproduce the sunlight bleaching before burial. The residual doses for the pIRIR 290 signal obtained from our loess samples are plotted against $\mathrm{D}_{\mathrm{e}}$ values (Fig. $3)$. There is a clear increase of the residual dose with $D_{e}$ value, although the two bottom samples (AS-TL4 and -8) have a different trend. The fitted line using 5 data points excluding AS-TL4 and -8 goes close to the origin, suggesting that there was no residual before burial.

The dose recovery ratio was satisfactory $( \pm 10 \%$ from the unity) for most of the samples for the pIRIR ${ }_{290}$ signal except the two bottom samples from each section which yielded lower dose recovery ratios, $\sim 0.8$ (AS-TL-4, and8 ; Table 3). The mean dose recovery ratio for $\mathrm{pIRIR}_{290}$ is

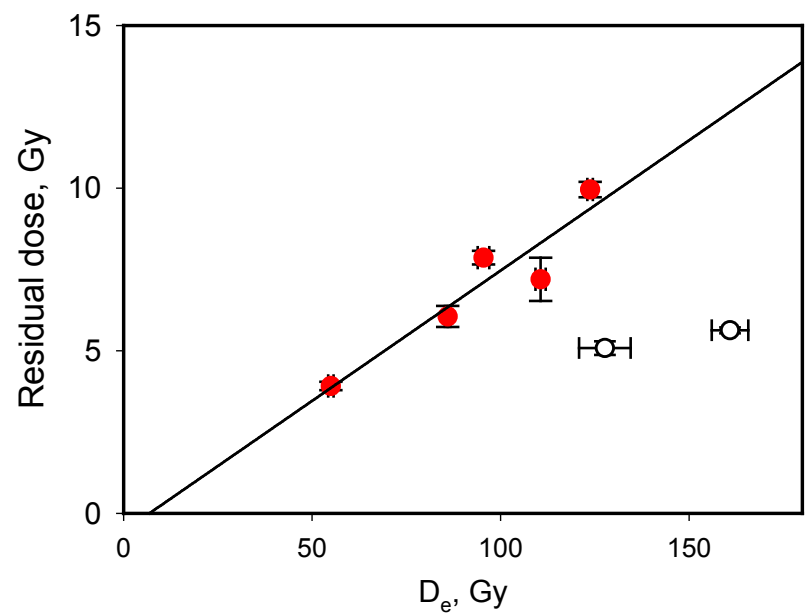

Fig. 3. Relationship between $D_{e}$ and residual dose for $I_{50}$ and pIRIR 290 signals from tephric loess samples.

Table 3. Equivalent dose and ages.

\begin{tabular}{|c|c|c|c|c|c|c|c|c|}
\hline Sample & Signal & $D_{e}(G y)^{*}$ & $\begin{array}{l}\sigma O D \\
(\%)\end{array}$ & $\begin{array}{c}\text { Residual dose } \\
\text { (Gy) }\end{array}$ & $\begin{array}{c}\text { Dose recovery } \\
\text { ratio }\end{array}$ & $\begin{array}{c}\text { g-value } \\
\text { (\%/decade) }\end{array}$ & $\begin{array}{l}\text { Fading uncor- } \\
\text { rected age (ka) }\end{array}$ & $\begin{array}{c}\text { Fading corrected } \\
\text { age (ka) }\end{array}$ \\
\hline$\overline{\text { AS-TL-1 }}$ & $\begin{array}{l}\mathrm{IR}_{50}(\mathrm{plR}) \\
\mathrm{pIRIR}_{290} \\
\text { pulsed OSL }\end{array}$ & $\begin{array}{l}44.3 \pm 0.8 \\
55.0 \pm 0.7 \\
46.4 \pm 1.3\end{array}$ & & $\begin{array}{l}1.5 \pm 0.1 \\
3.9 \pm 0.1\end{array}$ & $\begin{array}{l}0.97 \pm 0.03 \\
0.98 \pm 0.02 \\
0.90 \pm 0.01\end{array}$ & $\begin{array}{l}1.6 \pm 0.3 \\
1.0 \pm 0.1 \\
1.0 \pm 0.2\end{array}$ & $\begin{array}{l}15.1 \pm 1.1 \\
17.7 \pm 1.2 \\
19.1 \pm 1.4\end{array}$ & $17.3 \pm 1.4$ \\
\hline$\overline{\mathrm{AS}-\mathrm{TL}-2}$ & $\begin{array}{l}R_{50}(p \mid R) \\
\text { plRIR } 290 \\
\text { pulsed OSL }\end{array}$ & $\begin{array}{l}59.4 \pm 1.5 \\
95.5 \pm 1.5 \\
68.7 \pm 4.7\end{array}$ & & $\begin{array}{l}2.7 \pm 0.5 \\
7.9 \pm 0.2\end{array}$ & $\begin{array}{l}0.79 \pm 0.05 \\
0.98 \pm 0.02 \\
1.00 \pm 0.03\end{array}$ & $\begin{array}{l}1.6 \pm 0.4 \\
1.0 \pm 0.2 \\
1.0 \pm 0.6\end{array}$ & $\begin{array}{l}18.5 \pm 1.3 \\
27.9 \pm 1.9 \\
25.8 \pm 2.4\end{array}$ & $21.2 \pm 1.6$ \\
\hline AS-TL-3 & $\begin{array}{l}R_{50}(p \mid R) \\
\text { plRIR } 290 \\
\text { pulsed OSL }\end{array}$ & $\begin{array}{c}72.8 \pm 2.1 \\
124 \pm 1 \\
109 \pm 3\end{array}$ & & $\begin{array}{r}3.9 \pm 0.3 \\
10.0 \pm 0.2\end{array}$ & $\begin{array}{l}0.80 \pm 0.08 \\
1.09 \pm 0.05 \\
1.04 \pm 0.01\end{array}$ & $\begin{array}{r}1.4 \pm 0.3 \\
1.3 \pm 0.2 \\
-0.2 \pm 1.6 \\
\end{array}$ & $\begin{array}{l}25.6 \pm 2.0 \\
40.9 \pm 2.8 \\
46.0 \pm 3.5\end{array}$ & $29.4 \pm 2.4$ \\
\hline AS-TL-4 & $\begin{array}{l}R_{50}(p \mid R) \\
\text { plRIR } 290 \\
\text { pulsed OSL }\end{array}$ & $\begin{array}{c}95.0 \pm 1.9 \\
128 \pm 7 \\
75.3 \pm 6.3\end{array}$ & & $\begin{array}{l}2.1 \pm 0.2 \\
5.1 \pm 0.2\end{array}$ & $\begin{array}{l}0.73 \pm 0.07 \\
0.78 \pm 0.05 \\
0.90 \pm 0.14\end{array}$ & $\begin{array}{l}1.9 \pm 0.7 \\
0.4 \pm 0.2 \\
3.9 \pm 1.5\end{array}$ & $\begin{array}{l}37.8 \pm 3.0 \\
47.8 \pm 4.4 \\
35.9 \pm 4.1\end{array}$ & $\begin{array}{l}45.0 \pm 4.7 \\
50.3 \pm 9.1\end{array}$ \\
\hline AS-TL-7 & $\begin{array}{l}I_{50}(p I R) \\
\text { plRIR } 290 \\
\text { pulsed OSL }\end{array}$ & $\begin{array}{l}53.8 \pm 0.4 \\
85.9 \pm 0.7 \\
45.8 \pm 1.6\end{array}$ & & $\begin{array}{l}1.9 \pm 0.3 \\
6.1 \pm 0.3\end{array}$ & $\begin{array}{l}0.82 \pm 0.01 \\
1.00 \pm 0.02 \\
0.91 \pm 0.01\end{array}$ & $\begin{array}{l}1.8 \pm 0.4 \\
0.8 \pm 0.1 \\
0.9 \pm 0.4\end{array}$ & $\begin{array}{l}17.1 \pm 1.2 \\
25.7 \pm 1.7 \\
17.6 \pm 1.3\end{array}$ & $20.0 \pm 1.6$ \\
\hline AS-TL-8 & $\begin{array}{l}R_{50}(p \mid R) \\
\text { pIRIR } 290 \\
\text { pulsed OSL }\end{array}$ & $\begin{array}{c}71.9 \pm 2.5 \\
111 \pm 1 \\
84.1 \pm 11.2 \\
\end{array}$ & & $\begin{array}{l}2.7 \pm 1.6 \\
7.2 \pm 0.7\end{array}$ & $\begin{array}{l}0.91 \pm 0.21 \\
1.00 \pm 0.10 \\
1.04 \pm 0.05\end{array}$ & $\begin{array}{l}1.7 \pm 0.5 \\
1.0 \pm 0.4 \\
2.0 \pm 1.5\end{array}$ & $\begin{array}{l}28.5 \pm 2.5 \\
41.1 \pm 3.1 \\
40.6 \pm 6.3\end{array}$ & $\begin{array}{l}33.0 \pm 3.2 \\
47.2 \pm 8.9 \\
\end{array}$ \\
\hline$\overline{\text { AS-TL-9 }}$ & $\begin{array}{l}\mathrm{IR}_{50}(\mathrm{plR}) \\
\text { pIRIR } 290 \\
\text { pulsed OSL }\end{array}$ & $\begin{array}{c}149 \pm 7 \\
161 \pm 5 \\
72.0 \pm 6.9\end{array}$ & & $\begin{array}{l}2.2 \pm 0.7 \\
5.6 \pm 0.1\end{array}$ & $\begin{array}{l}0.84 \pm 0.06 \\
0.79 \pm 0.03 \\
0.92 \pm 0.01\end{array}$ & $\begin{array}{l}2.1 \pm 0.4 \\
0.5 \pm 0.2 \\
1.6 \pm 0.3\end{array}$ & $\begin{array}{l}70.5 \pm 6.9 \\
71.9 \pm 6.3 \\
40.5 \pm 5.4\end{array}$ & $\begin{array}{l}86.8 \pm 11.1 \\
46.2 \pm 6.3\end{array}$ \\
\hline$\overline{\text { AS-TGB-1 }}$ & $\begin{array}{l}\mathrm{IR}_{50}(\mathrm{pIR}) \\
\mathrm{pIRIR}_{300} \\
\mathrm{IR}_{50}\end{array}$ & $\begin{array}{l}177 \pm 12 \\
235 \pm 10 \\
139 \pm 6\end{array}$ & $\begin{array}{l}29 \\
17 \\
28 \\
\end{array}$ & $\begin{array}{l}4.0 \pm 0.9 \\
8.1 \pm 1.3\end{array}$ & $\begin{array}{l}1.32 \pm 0.14 \\
0.94 \pm 0.09 \\
0.95 \pm 0.04\end{array}$ & $0.7 \pm 0.7$ & $\begin{array}{l}68.3 \pm 6.5 \\
89.9 \pm 7.1 \\
53.6 \pm 4.2\end{array}$ & \\
\hline$\overline{\text { AS-TGB-2 }}$ & $\begin{array}{l}\mathrm{IR}_{50}(\mathrm{pIR}) \\
\mathrm{pIRIR}_{300} \\
\mathrm{IR}_{50}\end{array}$ & $\begin{array}{l}181 \pm 10 \\
221 \pm 8 \\
130 \pm 6\end{array}$ & $\begin{array}{l}23 \\
15 \\
30 \\
\end{array}$ & $\begin{array}{l}2.0 \pm 0.4 \\
6.9 \pm 0.8\end{array}$ & $\begin{array}{l}1.03 \pm 0.15 \\
0.87 \pm 0.03 \\
0.93 \pm 0.04\end{array}$ & $0.4 \pm 0.3$ & $\begin{array}{l}67.5 \pm 5.7 \\
81.7 \pm 6.1 \\
48.6 \pm 3.8\end{array}$ & \\
\hline$\overline{\text { AS-TGB-4 }}$ & $\begin{array}{l}\mathrm{IR}_{50}(\mathrm{pIR}) \\
\mathrm{pIRIR}_{300} \\
\mathrm{IR}_{50}\end{array}$ & $\begin{array}{l}223 \pm 9 \\
241 \pm 7 \\
158 \pm 6\end{array}$ & $\begin{array}{l}16 \\
10 \\
22\end{array}$ & $\begin{array}{l}3.7 \pm 1.0 \\
7.3 \pm 0.8\end{array}$ & $\begin{array}{l}1.09 \pm 0.16 \\
0.87 \pm 0.07 \\
0.94 \pm 0.04\end{array}$ & $0.7 \pm 0.4$ & $\begin{array}{c}93.6 \pm 7.8 \\
101 \pm 8 \\
66.5 \pm 5.4\end{array}$ & \\
\hline
\end{tabular}

${ }^{*} D_{e}$ values were calculated using arithmetic mean for AS-TL-1-9 and the Central Age Model for AS-TGB-1, 2, and 4.

Only the aliquots with a recycling ratio of $\pm 10 \%$ from the unity were used for the $D_{e}$ calculation. 
$0.95 \pm 0.04$, but tended to underestimate for the $\mathrm{IR}_{50}$ signal (0.81 \pm 0.03 ; Table 3). The $\mathrm{IR}_{50}$ and $\mathrm{pIRIR}_{290} \mathrm{D}_{\mathrm{e}}$ values were measured using 6 aliquots for each sample and ranged from 44 to 149 Gy for $\mathrm{IR}_{50}$ and 55 to $161 \mathrm{~Gy}$ for pIRIR 290 .

An anomalous fading test was conducted using a procedure following Auclair et al. (2003) by repeatedly measuring regenerated $\left(\mathrm{L}_{\mathrm{x}}\right)$ and test dose $\left(\mathrm{T}_{\mathrm{x}}\right)$ signals with various durations of delay (0.2-50 hours) between the irradiation and the $\mathrm{L}_{\mathrm{x}}$ measurements. The fading rate (g-value) for $\mathrm{IR}_{50}$ is between 1.4 and $2.1 \% /$ decade and that for pIRIR $_{290}$ signals is between than 0.4 and $1.3 \% /$ decade, confirming that the fading is negligible for pIRIR $_{290}$ signal and therefore, there is no need for a fading correction (Buylaert et al., 2012). Such small fading rate of $<1.3 \%$ /decade has been almost always measured from the pIRIR ${ }_{290}$ signal, which has been considered as a laboratory artefact (Thiel et al., 2011a, 2011b; Buylaert et al., 2012). The resulting pIRIR 290 ages for tephric loess are ranging from 18 to $44 \mathrm{ka}$ for Site 1 and from 18 to $72 \mathrm{ka}$ for Site 2 (Table 3 ). The $\mathrm{IR}_{50}$ ages were corrected for anomalous fading using the method of Huntley and Lamothe (2001), and the fading corrected ages are still underestimating the pIRIR 290 ages for 4 samples (out of 7). This could be because of the low dose recovery ratio of $\mathrm{IR}_{50}$ signal (Table 3 ), and therefore we conclude that our $\mathrm{IR}_{50}$ ages from the tephric loess measured as a part of the pIRIR 290 protocol are less reliable than the pIRIR 290 ages.

\section{Pulsed OSL}

Pulsed OSL $D_{e}$ values were measured by pulsed blue LED stimulation (50 $\mu \mathrm{s}$ on, $50 \mu \mathrm{s}$ off) for $200 \mathrm{~s}$ using a preheat of $220^{\circ} \mathrm{C}$ for $10 \mathrm{~s}$ and a cut heat of $200^{\circ} \mathrm{C}$ (Table 2). An IR bleaching for $200 \mathrm{~s}$ was always inserted before the pulsed OSL stimulations to bleach feldspar OSL signal as much as possible before stimulating with blue LEDs. Although pulsed OSL is a powerful method to obtain quartz dominated OSL signals from a mixed quartz/feldspar sample, its effectiveness depends on the contribution of quartz OSL in the bulk OSL signal. If there is too little quartz in polymineral fine grain samples, the pulsed OSL can be still dominated by feldspar OSL signal. Interestingly, the intensity of pulsed OSL signal (measured as a test dose OSL after 48 Gy beta irradiation) decreased significantly with depth for both Site 1 and 2. Fig. 4 shows the test dose OSL signals for 4 samples from Site 1. This suggests that the amount of quartz in the loess have been increased with time. Such a difference in the luminescence intensity was not observed in the IRSL and pIRIR signals.

A dose recovery test was done by bleaching natural OSL signal using blue LEDs for $500 \mathrm{~s}$ twice then giving a dose of $72 \mathrm{~Gy}$ as a surrogate of natural dose. A fading test was also conducted with delays between 0.2 and 26 hours, because it is possible that not all pulsed OSL originates from quartz, as mentioned above.
The dose recovery ratios for all samples are within the acceptable range (0.9-1.1, Table 3$)$. The fading rates are negligible for samples (AS-TL-1, 2, 3, and 7: $0-1.0 \% /$ decade). However, the g-values are larger for the other three samples whose signals are $\operatorname{dim}$ (AS-TL-4, 8, and 9: $1.6-3.9 \% /$ decade), and the ages of these samples were corrected for fading using the method of Huntley and Lamothe (2001). The final pulsed OSL ages (fading corrected or uncorrected, depending on the fading rate) are listed in Table 3.

\section{Comparison between IRSL, pIRIR and pulsed OSL ages of tephric loess}

The luminescence characteristics of different signals suggests that all pIRIR ${ }_{290}$ ages and the pulsed OSL ages for 4 samples (AS-TL-1, 2, 3, 7), whose signals showed negligible fading, are more reliable than all $\mathrm{IR}_{50}$ ages and rest of the pulsed OSL ages which needed fading corrections. The pIRIR 290 and pulsed OSL signals have good dose recovery ratios for most of the samples whereas $I_{50}$ dose recovery ratio underestimates from the unity. Therefore, we exclude the $\mathrm{IR}_{50}$ ages (as measured part of the pIRIR 290 protocol) from our interpretation.

The difference in the characteristics of pulsed OSL signal between the samples presumably reflects the change in the dominant source of loess. The pulsed OSL signal from AS-TL-1, 2, 7 are in particular, much brighter than the other samples, probably because the samples contain more aeolian loess component from the Asian continent, rather than the local origin.

Fig. 5 shows $I_{50}$, pIRIR 290 and pulsed OSL ages for all tephric loess samples. All pIRIR ${ }_{290}$ and pulsed OSL ages from 4 samples from Site 1 are consistent within 1- $\sigma$ uncertainty, ranging from $\sim 18-19$ ka up to $\sim 48-50$ ka. However, the ages from Site 2 show larger scatter in ages obtained from different methods. For AS-TL- 8 the pIRIR $_{290}$ and pulsed OSL ages agreed and yielded similar ages (41-47 ka). However, the pIRIR 290 and pulsed OSL

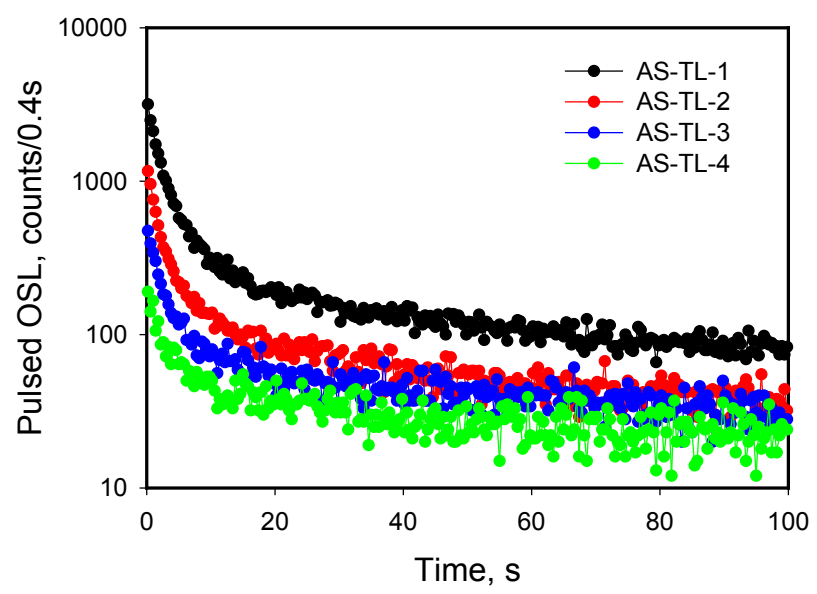

Fig. 4. Pulsed OSL decay curves for AS-TL-1-4 from Site 1. 
ages are significantly different for the lowermost sample, AS-TL-9 (72 \pm 6 ka for pIRIR $290,46 \pm 6$ ka for pulsed OSL after fading correction). The pulsed OSL signal from this sample was very dim, suggesting the sample contains very little amount of quartz, and therefore, pulsed OSL is not a suitable method for this sample. The pIRIR 290 age of $72 \pm 6 \mathrm{ka}$ should be more reliable, despite the lower dose recovery ratio $(0.79 \pm 0.03)$. We therefore regard $72 \pm 6 \mathrm{ka}$ as a preliminary minimum age of Takuma gravel bed.

\section{IRSL and post-IR IRSL dating of Takuma gravel bed}

Plagioclase originated from Aso volcano is relatively Ca-rich (between $\mathrm{An}_{37}$ and $\mathrm{An}_{86}$, according to Hunter, 1998). This type of feldspar has been only limitedly applied to luminescence dating for estimating ages of volcanic eruption (e.g. Tsukamoto et al., 2010; 2011), but has not yet been used for dating sediments containing volcaniclastic materials settled by water processes. From the luminescence studies of basalt including Ca-rich plagioclase, very high fading rates of up to $\sim 30 \%$ /decade were reported by Morthekai et al. (2008) and Tsukamoto and Duller (2008).

Since minimising anomalous fading is a critical issue in dating volcanic plagioclase, a post-IR IRSL protocol with a preheat at $340^{\circ} \mathrm{C}$ for $60 \mathrm{~s}$ and pIRIR stimulation temperature of $300^{\circ} \mathrm{C}(400 \mathrm{~s})$ was selected for Takuma gravel bed samples (Table 2). The higher preheat temperature reduces the number of possible recombination centres, and therefore reduces the chance of anomalous fading (Jain and Ankjærgaard, 2011). Fig. 6 shows IR $_{50}$ and pIRIR $_{300}$ decay curves and dose response curves for an aliquot of AS-TGB-1. The $\mathrm{IR}_{50}$ signal is very dim compared to the pIRIR ${ }_{300}$ signal after applying the $340^{\circ} \mathrm{C}$ preheat. A dose recovery and a fading test were also conducted for all three samples in the same manner as with the tephric loess samples. The integrated intensity of the first $4 \mathrm{~s}$ minus last $10 \mathrm{~s}$ was used for the $\mathrm{IR}_{50}$ signal,

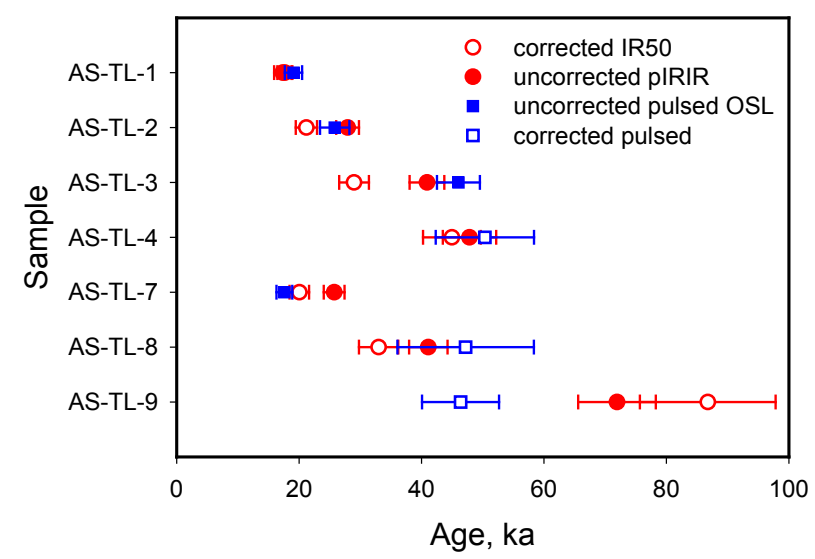

Fig. 5. Summary of $I R_{50}$, pIRIR 290 and pulsed OSL ages for all tephric loess samples. and the intensity of the initial $20 \mathrm{~s}$ minus last $80 \mathrm{~s}$ was used for the pIRIR 300 signal. The dose recovery ratios after subtracting the residual doses are ranging from $1.03 \pm 0.15$ to $1.32 \pm 0.14$ for the $\mathrm{IR}_{50}$ signal and from $0.87 \pm 0.03$ to $0.94 \pm 0.09$ for the $\mathrm{pIRIR}_{300}$ signal. The measured anomalous fading rates were negligible for the pIRIR $_{300} \quad$ signal; $\quad 0.68 \pm 0.72, \quad 0.44 \pm 0.32, \quad$ and $0.69 \pm 0.42 \% /$ decade for AS-TGB-1, -2 , and -4 , indicating that there is no need for a fading correction. However, there was a significant scatter in the fading rates between aliquots for the $\mathrm{IR}_{50}$ signal. Some aliquots showed clear increase with the delay time after irradiation. Thiel et al. (2011b) also reported minus fading rates from some of their samples from Japanese tephric loess; the reason has not been understood. Therefore we did not apply a fading correction for the $\mathrm{IR}_{50}$ ages from the Takuma gravel bed. The $D_{e}$ values were measured with using $6 \mathrm{~mm}$ aliquots, and were calculated with the Central Age Model (CAM) by Galbraith et al. (1999). The pIRIR ${ }_{300} \mathrm{D}_{\mathrm{e}}$ values have tight and normal dose distributions of the pIRIR $D_{e}$ val-
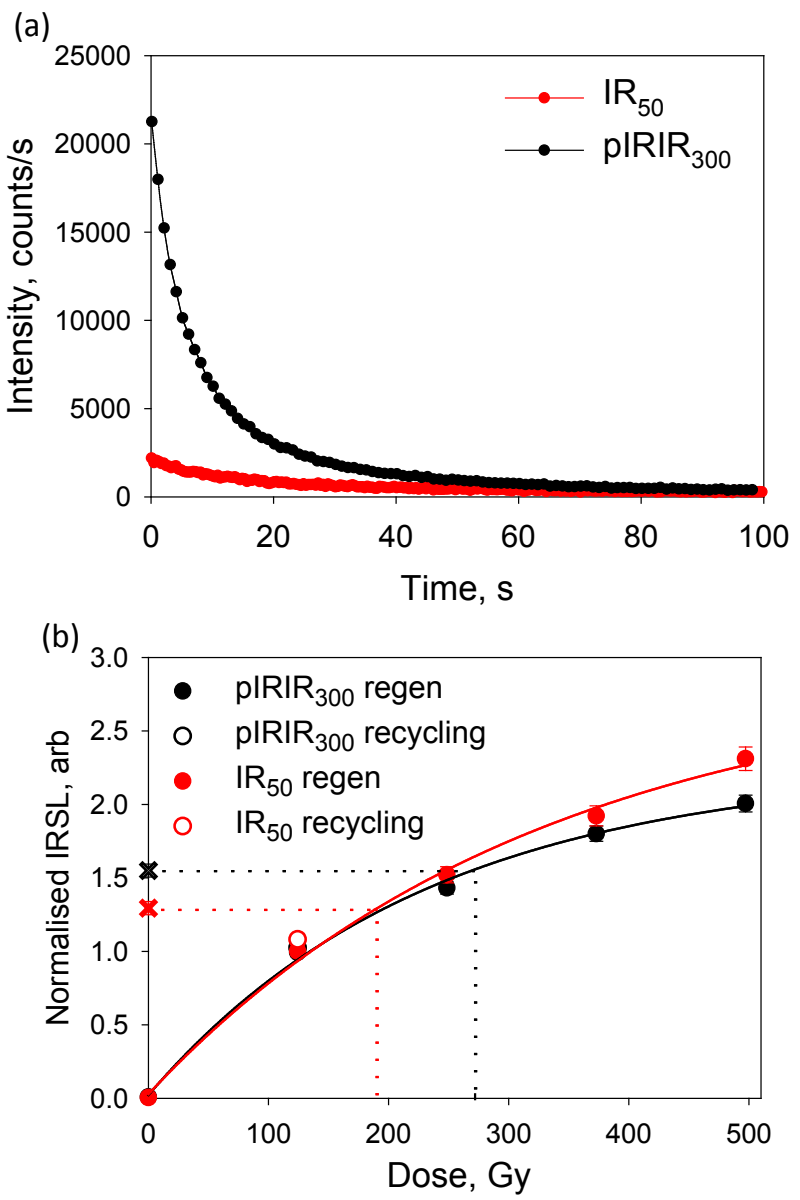

Fig. 6. (a) Decay curves of IRSL signal at $50^{\circ} \mathrm{C}$ (IR50) and post-IR IRSL (pIRIR300) signal at $300^{\circ} \mathrm{C}$ from one aliquot from AS-TGB-1. (b) Dose response curves for $I R_{50}$ and pIRIR ${ }_{300}$ signals from the same sample. 
ues (Fig. 7a) with overdispersions of between 10 and $17 \%$. The pIRIR 300 ages were calculated to $90 \pm 7,82 \pm 6$, and $101 \pm 8$ ka for AS-TGB-1, -2 , and -4 , respectively, which are comparable with that of Aso-4 (86.8-87.3 ka, Aoki, 2008). These data suggest that the pIRIR ${ }_{300}$ signal was not bleached at all at deposition, but probably reset by the last caldera-forming eruption event (Aso-4). This is not surprising because it is thought that the Takuma gravel bed was probably deposited in a very short period of time rather than normal fluvial sediments deposited under a perennial streamflow condition, and pIRIR signals are known to be very difficult to bleach (Buylaert et al. 2012). Nevertheless, the three pIRIR 300 ages from the Takuma gravel bed can be used as maximum age of the deposition of the bed. Since all the three pIRIR 300 ages are likely to indicate the same resetting event, the weighted mean of the ages was calculated to be $89 \pm 3 \mathrm{ka}$.

It is known that the $\mathrm{IR}_{50}$ signal bleaches faster than a high temperature pIRIR signal (Buylaert et al., 2012). We measured the $\mathrm{IR}_{50}$ signal as a part of the pIRIR 300 protocol (Table 3), but as mentioned above, it was not possible to calculate g-values for each sample and therefore the fading corrected ages were not calculated. In order to investigate whether the $\mathrm{IR}_{50}$ signal had been bleached at deposition, $D_{e}$ values from a number of small aliquots (using $2.5 \mathrm{~mm}$ aliquot size) was measured using an IRSL SAR protocol (Table 2) with a preheat at $280^{\circ} \mathrm{C}(60 \mathrm{~s})$. The same preheat temperature as we used in the pIRIR protocol $\left(340^{\circ} \mathrm{C}\right)$ could not be used, because the high preheat temperature reduces the $\mathrm{IR}_{50}$ signal intensity, and the signal is almost undetectable if a small aliquot is used. The dose distribution of $\mathrm{IR}_{50}$ signal $\left(280^{\circ} \mathrm{C}\right.$ preheat shown in Fig. $7 \mathbf{b}$ are not skewed as expected from an incompletely bleached sample. Thus it is likely that the $\mathrm{IR}_{50}$ signal has also not been bleached before the deposition of the Takuma gravel bed. However, it is also possible that there were small portion of grains which had been bleached at the flood event but our multigrain measurements could not detect such grains.

One interesting phenomena was observed from the fading test of the $\mathrm{IR}_{50}$. The g-values were calculated using the same integration limit as we used for the $\mathrm{D}_{\mathrm{e}}$ (initial $10 \mathrm{~s}$ minus the last $20 \mathrm{~s}$ ) and then very high fading rates were obtained. It is impossible to correct the anomalous fading accurately with such high fading rates (7-12\%). The g-values were also calculated at different integration limits (10-20 s and 20-60 s) and interestingly the values were drastically decreased (Fig. 8a). Similar reduction of g-values was reported by previous studies (Thomsen et al., 2008; Novothny et al., 2010) and was also expected from the model of feldspar luminescence production (Jain and Ankjærgaard, 2011; Jain et al., 2012). The reduction of g-values is expected to be accompanied by an increasing $D_{e}$ values towards the latter part of the decay curve. We calculated $D_{e}$ values for the all three integration limits (Fig. 8b), however, the $D_{e}$ value did not change with the integration limit. We there- (a)
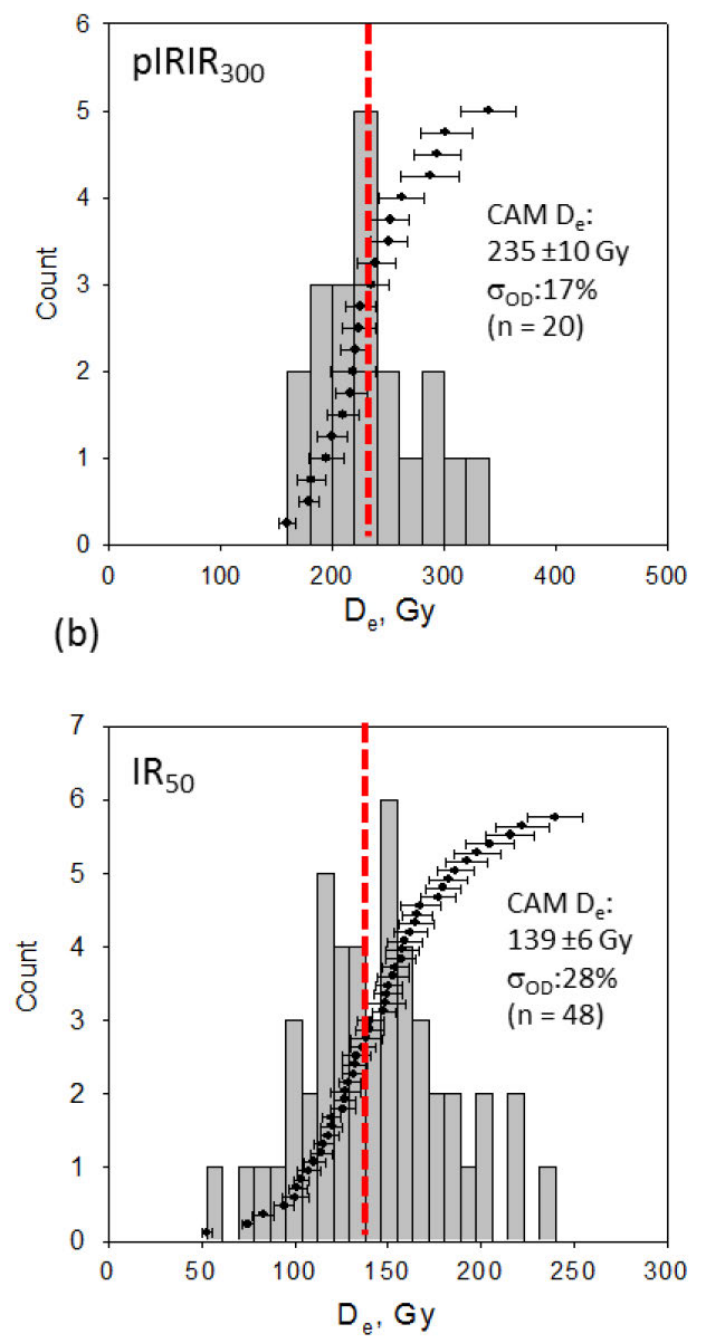

Fig. 7. $D_{e}$ distributions of (a) pIRIR $R_{300}$ signal using medium aliquot and (b) IR50 signal using small aliquots from AS-TGB-1.

fore could not select a g-value for fading correction for the $\mathrm{IR}_{50}$ ages, and it was not possible to calculate fading corrected $\mathrm{IR}_{50}$ ages.

\section{SUMMARY}

The pIRIR 290 ages from loess deposits overlying the Takuma gravel bed suggest a minimum age of the Takuma gravel bed of $\sim 72 \mathrm{ka}$. The pIRIR $_{300}$ signal from plagioclase showed negligible anomalous fading. However, pIRIR ${ }_{300} D_{\mathrm{e}}$ values showed a tight dose distribution and the age is indistinguishable from the Aso-4 eruption age. The age of the Takuma gravel bed is likely to be constrained between $\sim 72$ and $89 \mathrm{ka}$ from the result of this study. 
(a)

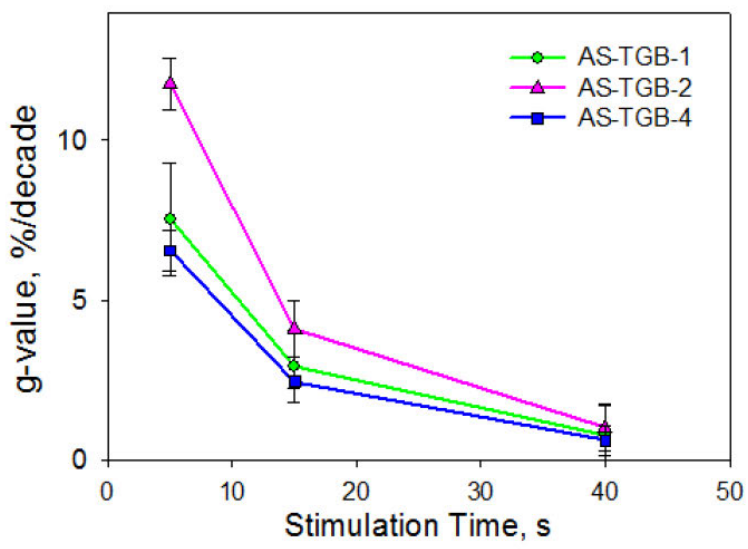

(b)

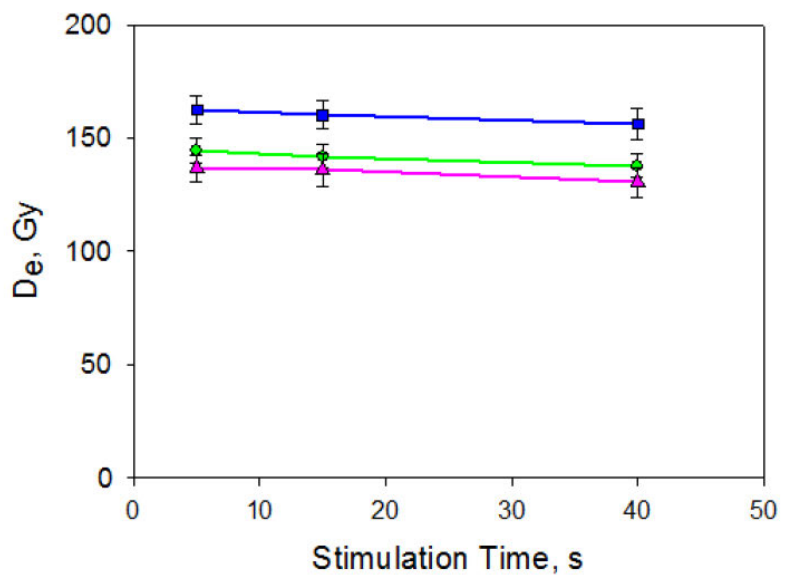

Fig. 8. (a) Variation in $g$-values of $I R_{50}$ signal from Takuma gravel bed samples with different signal integration limits. (b) $D_{e}$ values at corresponding integration limits as in (a).

\section{ACKNOWLEDGEMENTS}

The authors thank Dr. Hideo Kubotera and the National Agriculture Research Centre for Kyushu Okinawa Region for permission and logistic support during sampling at the research centre. Jingran Zhang, Sabine Mogwitz, and Sonja Riemenschneider of Leibniz Institute for Applied Geophysics are thanked for their help in sample preparation and the gamma spectrometry measurements. Dr. Reiner Dorhmann of Federal Institute for Geosciences and Natural Resources (BGR) is thanked for the XRD analysis. Funding for this study was provided by the Japanese Ministry of Education, Culture, Sports, Science and Technology (PI: Kyoko S. Kataoka, no. 2074294, Grant-in-Aid for Young Scientists (B) category) and by the Kurita Water and Environment Foundation (PI: Kyoko S. Kataoka, Research Grant Program no. 23343).

\section{REFERENCES}

Aoki K, 2008. Revised age and distribution of ca. 87 ka Aso-4 tephra based on new evidence from the northwest Pacific Ocean. Quaternary International 178(1): 100-118, DOI 10.1016/j.quaint.2007.02.005.

Auclair M, Lamothe M and Huot S, 2003. Measurement of anomalous fading for feldspar IRSL using SAR. Radiation Measurements 37(4-5): 487-492, DOI 10.1016/S1350-4487(03)00018-0.

Buylaert J-P, Jain M, Murray AS, Thomsen KJ, Thiel C and Sohbati R, 2012. A robust method for increasing the age range of feldspar IRSL dating. Boreas 41(3): 435-451, DOI $10.1111 / \mathrm{j} .1502$ 3885.2012.00248.x.

Denby PM, Bøtter-Jensen L, Murray AS, Thomsen KJ and Moska P, 2006. Application of pulsed OSL to the sepration of the luminescence components from a mixture of quartz/feldspar samples. $R a$ diation Measurements 41(7-8): 774-779, $\quad$ DOI 10.1016/j.radmeas.2006.05.017.

Frechen M, Schweitzer U and Zander A, 1996. Improvements in sample preparation for the fine grain technique. Ancient TL 14: 15-17.

Galbraith RF, Roberts RG, Laslett GM, Yoshida H and Olley JM, 1999. Optical dating of single and multiple grains of quartz from Jinmium rock shelter, Northern Australia: part 1, experimental details and statistical models. Archaeometry 41(2): 339-364, DOI 10.1111/j.1475-4754.1999.tb00987.x.

Guérin G, Mercier N and Adamiec G, 2011. Dose-rate conversion factors: update. Ancient TL 29: 5-8.

Hunter AG, 1998. Intracrustal Controls on the Coexistence of Tholeiitic and Calc-alkaline Magma Series at Aso Volcano, SW Japan. Journal of Petrology 39(7): 1255-1284, DOI 10.1093/petroj/39.7.1255.

Huntley DJ and Lamothe M, 2001. Ubiquity of anomalous fading in Kfeldspars and the measurement and correction for it in optical dating. Canadian Journal of Earth Sciences 38(7): 1093-1106, DOI 10.1139/e01-013.

Jain M, Guralnik B and Andersen M, 2012. Stimulated luminescence emission from localized recombination in randomly distributed defects. Journal of Physics, Condensed Matter 24(38): 385402, DOI 10.1088/0953-8984/24/38/385402.

Jain M and Ankjærgaard C, 2011. Towards a non-fading signal in feldspar: Insight into charge transport and tunnelling from timeresolved optically stimulated luminescence. Radiation Measurements 46(3): 292-309, DOI 10.1016/j.radmeas.2010.12.004.

Kataoka KS, 2011. Geomorphic and sedimentary evidence of a gigantic outburst flood from Towada caldera after the $15 \mathrm{ka}$ TowadaHachinohe ignimbrite eruption, northeast Japan. Geomorphology 125(1): 11-26, DOI 10.1016/j.geomorph.2010.08.006.

Kataoka KS and Miyabuchi Y, 2011. Outflow event from the Aso caldera lake. 2011 PERC Planetary Geology Field Symposium Guidebook for fieldtrip 37-40.

Kataoka KS, Urabe A, Manville V and Kajiyama A, 2008. Breakout flood from an ignimbrite-dammed valley after the Numazawako eruption, northeast Japan. Geological Society of America Bulletin 120(9-10): 1233-1247, DOI 10.1130/B26159.1.

Kreuzer S, Schmidt C, DeWitt R and Fuchs M, submitted. The a-value of polymineral fine grain samples measured with the post-IR IRSL protocol. Radiation Measurements.

Lai ZP, Zöller L, Fuchs M and Brückner H, 2008. Alpha efficiency determination for OSL of quartz extracted from Chinese loess. $R a$ diation Measurements 43(2-3): 767-770, DOI 10.1016/j.radmeas.2008.01.022.

Lapp T, Jain M, Ankjærgaard C and Pirtzel L, 2009. Development of pulsed stimulation and Photon Timer attachments to the Risø TL/OSL reader. Radiation Measurements 44(5-6): 571-575, DOI 10.1016/j.radmeas.2009.01.012.

Machida H and Arai F, 2003. Atlas of tephra in and around Japan (revised version). The University of Tokyo Press, 337p (in Japanese).

Manville V, White JDL, Houghton BF and Wilson CJN, 1999. Paleohydrology and sedimentology of a post-1.8 ka breakout flood from intracaldera Lake Taupo, North Island, New Zealand. Geological 
Society of America Bulletin 111(10): 1435-1447, DOI 10.1130/0016-7606(1999)111<1435:PASOAP >2.3.CO;2.

Morthekai P, Jain M, Murray AS, Thomsen K and Bøtter-Jensen L, 2008. Fading characteristics of martian analogue materials and the applicability of a correction procedure. Radiation Measurements 43(2-6): 672-678, DOI 10.1016/j.radmeas.2008.02.019.

Novothny A, Frechen M, Horvath E, Krbetchek M and Tsukamoto S, 2010. Infrared stimulated luminescence and radiofluorescence dating of aeolian sediments from Hungary. Quaternary Geochronology 5(2-3): 114-119, DOI 10.1016/j.quageo.2009.05.002.

Ono K and Watanabe K, 1985. Geological map of Aso Volcano (1:50,000). Geological Map of Volcanoes 4. Geological Survey of Japan (in Japanese with English abstract).

Ono K, Matsumoto Y, Miyahisa M, Teraoka Y and Kambe N, 1977. Geology of the Taketa district. Geological Survey of Japan, 145p (in Japanese with English abstract).

Park C and Schmincke H-U, 1997. Lake formation and catastrophic dam burst during the Late Pleistocene Laacher See eruption (Germany). Naturwissenschaften 84: 521-525.

Prescott JR and Hutton JT, 1994. Cosmic ray contributions to dose rates for luminescence and ESR dating: Large depths and long-term time variations. Radiation Measurements 23(2-3): 497-500, DOI 10.1016/1350-4487(94)90086-8.

Sohbati R, Murray AS, Buylaert JP, Ortuño M, Cunha PP and Masana E, 2012. Luminescence dating of Pleistocene alluvial sediments affected by the Alhama de Murcia fault (eastern Betics, Spain) - a comparison between OSL, IRSL and post-IR IRSL ages. Boreas 41(2): 250-262, DOI 10.1111/j.1502-3885.2011.00230.x.

Suzuki T, 1995. Origin of so-called volcanic ash soil: thickness distribution in and around central Japan. Bulletin of the Volcanological Society of Japan 40: 167-176 (in Japanese with English abstract).

Thiel C, Buylaert J-P, Murray AS, Terhorst B, Hofer I, Tsukamoto S and Frechen M, 2011a. Luminescence dating of the Stratzing loess profile (Austria) - Testing the potential of an elevated temperature post-IR IRSL protocol. Quaternary International 234(1-2): 23-31, DOI 10.1016/j.quaint.2010.05.018.

Thiel C, Buylaert J-P, Murray AS and Tsukamoto S, 2011b. On the applicability of post-IR IRSL dating to Japanese loess. Geochronometria 38(4): 369-378, DOI 10.2478/s13386-011-0043-4.

Thomsen KJ, Murray AS, Jain M, Bøtter-Jensen L, 2008. Laboratory fading rates of various luminescence signals from feldspar-rich sediment extracts. Radiation Measurements 43(9-10): 1474-1486, DOI 10.1016/j.radmeas.2008.06.002.

Tsukamoto S and Duller GAT, 2008. Anomalous fading of various luminescence signals from terrestrial basaltic samples as Martian analogues. Radiation Measurements 43(2-6): 721-725, DOI 10.1016/j.radmeas.2007.10.025.

Tsukamoto S, Duller GAT, Wintle AG and Muhs D, 2011. Assessing the potential for luminescence dating of basalts. Quaternary Geochronology 6(1): 61-70, DOI 10.1016/j.quageo.2010.04.002.

Tsukamoto S, Duller GAT, Wintle AG and Frechen M, 2010. Optical dating of a Japanese marker tephra using plagioclase. Quaternary Geochronology $\quad 5(2-3): \quad 274-278, \quad$ DOI 10.1016/j.quageo.2009.02.002.

Tsukamoto S, Murray AS, Huot S, Watanuki T, Denby PM and BøtterJensen L, 2007. Luminescence property of volcanic quartz and the use of red isothermal TL for dating tephras. Radiation Measurements 42(2): 190-197, DOI 10.1016/j.radmeas.2006.07.008.

Tsukamoto S, Rink WJ and Watanuki T, 2003. OSL of tephric loess and volcanic quartz in Japan and an alternative procedure for estimating $\mathrm{D}_{\mathrm{e}}$ from a fast OSL component. Radiation Measurements 37(45): 459-465, DOI 10.1016/S1350-4487(03)00054-4.

Watanabe K, 1998. Shin-Kumamoto-Shishi (History of Kumamoto City), 103-108 (in Japanese).

Watanabe K, Takada H, Okabe R and Nishida A, 1995. Stratigraphic relation between fluvial terrace deposits and widespread tephra beds in the middle reaches of the Shirakawa, Kumamoto Prefecture, Japan. Memoirs of the Faculty of Education, Kumamoto University. 44, 15-22 (in Japanese with English abstract).

Watanuki T, Murray AS and Tsukamoto S, 2005. Quartz and polymineral luminescence dating of Japanese loess over the last 0.6 Ma: comparison with an independent chronology. Earth and Planetary Science Letters 240(3-4): 774-789, DOI 10.1016/j.eps1.2005.09.027.

Wada K, 1987. Minerals formed and mineral formation from volcanic ash by weathering. Chemical Geology 60(1-4): 17-28, DOI 10.1016/0009-2541(87)90106-9.

Waythomas CF, Walder JS, McGimsey RG and Neal CA, 1996. A catastrophic flood caused by drainage of a caldera lake at Aniakchak Volcano, Alaska, and implications for volcanic hazards assessment. Geological Society of America Bulletin 108(7): 861-871, DOI 10.1130/0016-7606(1996)108<0861:ACFCBD>2.3.CO;2. 